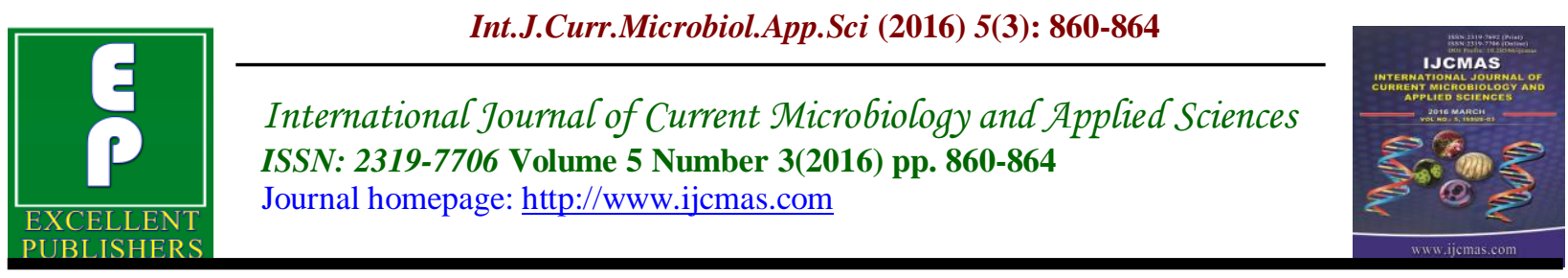

Original Research Article

http://dx.doi.org/10.20546/ijcmas.2016.503.099

\title{
Biosynthesis of Clot Busting Fibrinolytic Enzyme from Aspergillus japonicum by Supplementing Carbon Sources
}

\author{
Saroj $\operatorname{Yadav}^{1}$ and K. G. Siddalingeshwara ${ }^{2 *}$ \\ ${ }^{1}$ Research and Development, Bharathiar University, Coimbatore \\ ${ }^{2}$ Scientific \& Industrial Research Centre, Bangalore \\ *Corresponding author
}

\begin{abstract}
A B S T R A C T
Keywords

Carbon source, Clot buster drug, Fibrin carbon source, Aspergillus japonicum.

\section{Article Info}

Accepted: 20 February 2016 Available Online: 10 March 2016

Fibrinolytic enzymes that dissolve blood clots and show promise for thrombosis therapy have been successfully identified from various sources. A wide range of microorganisms has been screened for their fibrinolytic properties. The Aspergillus Japonicum KGSS 05 were isolated from different soils from different regions of Karnataka and screened for fibrinolytic activity by plate assay.The potential strain Aspergillus Japonicum KGSS 05 were used for the enhance the biosynthesis of fibrinolytic enzyme by supplementation of carbon sources were employed in range of $0.25 \%$ to $1.25 \%$. The carbon source were supplemented are glucose, sucrose and maltose. Among the carbon source the glucose showed better yield of 246 IU fibrinolytic enzyme production and maltose and sucrose showed 123 IU and 176 IU.
\end{abstract}

\section{Introduction}

Disorders of blood clotting and fibrinolysis are serious medical problems. Thrombosis, which is particularly serious, can lead to cerebral and myocardial infarction due to un-lysed blood clots (Holden 1990). A number of proteases that can interfere with blood clotting have been purified and characterized from various sources including microorganisms. Some of these proteases are fibrinolytic enzymes capable of digesting fibrin (Sumi et al., 1995).

The fibrinolytic agents available for clinical use are mostly plasminogen activators, such as tissue-type plasminogen activator, urokinase-type plasminogen activator and the bacterial plasminogen activator, streptokinase. In spite of their widespread use, these agents display low specificity to fibrin, are very expensive and cause undesired effects. Consequently, the search continues for plasmin-like fibrinolytic enzymes from various sources for use in thrombolytic therapy (Holden 1990).

Fibrinolytic enzymes that dissolve blood clots and show promise for thrombosis therapy have been successfully identified 
from various sources. A wide range of microorganisms has been screened for their fibrinolytic properties (Takeno et al., 1999). Fibrinolytic enzymes have been purified, cloned and studied from many plants, animals and microbial sources [3]. The agents are of interest as useful tools for understanding fibrinolytic mechanism and as potential therapeutic drugs.

In this study, a potent fibrinolytic enzymeproducing fungi were isolated from different soil samples and identified as Aspergillus japonicum and used for biosynthesis through submerged fermentation by supplementation carbon source were carried out and achieved an enhanced level.

\section{Materials and Methods}

\section{Fungal Strain}

Aspergillus japonicum were isolated from soils collected from different regions in and around Bangalore. The Aspergillus japonicum were isolated by using Czapek Dox's media and tentatively identified in the laboratory and confirmed at Agharakar Research Institute, Pune.

\section{Screening of Fibrinolytic Enzyme Producers by Plate Assay}

Fibrinolytic activity was determined using the method described by Astrup and Mullertz (). The fibrin agarose plate was made to a $1 \mathrm{~mm}$ thickness, and contained agarose $(1.2 \% \mathrm{w} / \mathrm{v})$, bovine fibrinogen $(0.4 \% \mathrm{w} / \mathrm{v})$, and bovine thrombin $(20 \mathrm{U} / \mathrm{mL})$ in a petridisc, and the clot was allowed to stand for $1 \mathrm{~h}$ at room temperature. Then, 10 $\mu \mathrm{L}$ of sample enzyme solution was carefully placed onto the plate. The plate was incubated for $5 \mathrm{~h}$ at $37^{\circ} \mathrm{C}$ and the diameter of the lytic zone was measured and the clear transparent region was observed in which fibrin is hydrolyzed.
Supplementation of Carbon Source for the Biosynthesis of Fibrinolytic Enzyme

The production medium supplemented with a particular carbon source with concentrations ranging from $0.25 \%$ to $1.25 \%$ with increments of $0.25 \%$. The different carbon sources like, monosaccharides (glucose) and disaccharides (Sucrose and Maltose) were used under the present study. The production medium consists $(\mathrm{mg} / 100 \mathrm{ml})$ of Sucrose 3, di potassium hydrogen phosphate 0.1, MgSO4,0.05g, KCl 0.05g, $\mathrm{NaCl}$, $0.01 \%, \mathrm{FeSO} 4$ and devoid of sucrose. The condition of the fermentation medium is as fallows.pH,6 temperature $30^{\circ} \mathrm{C}$ and inoculums size is of $1.0 \mathrm{ml}$.

\section{Extraction of Fibrinolytic Enzymes}

The fermentation medium were withdrawn periodically at $24 \mathrm{hrs}$ in aseptic condition. The extract was filtered through Whatman filter No.1. The clear extract was centrifuged at 2000-3000 rpm for 15-20 min, supernatant were used as fibrino enzyme preparation. Thus prepared crude enzyme was used for assay of fibrinolytic enzyme.

\section{Fibrinolytic Enzyme Assay}

This was basically measured by the modified method of Anson [5], but with a few modifications. The reaction mixture contained $1 \mathrm{ml}$ of $1.2 \%$ of bovine fibrin solution in Tris- $\mathrm{HCl}$ buffer ( $\mathrm{pH} \mathrm{8.0)}$ ) and 1 $\mathrm{ml}$ of cell-free supernatant (CFS). The reaction mixture was incubated for $2 \mathrm{~h}$ at $37^{\circ} \mathrm{C}$. Then the reaction was stopped by the addition of $2 \mathrm{ml}$ of $10 \% \quad(\mathrm{w} / \mathrm{v})$ trichloroacetic acid. This was followed by centrifugation and assaying the solubilized proteins for tyrosine in the supernatant by measuring the absorbance at $750 \mathrm{~nm}$ [6]. 


\section{Unit}

One unit of fibrinolytic activity (U) was defined as the amount of enzyme required to liberate $1 \mu \mathrm{g}$ of L-tyrosine $/ \mathrm{ml} / \mathrm{min}$ at $37^{\circ} \mathrm{C}$

\section{Results and Discussion}

The Aspergillus tamari strain were isolated and screened for fibrinolytic enzyme production by fibrin plate assay. The potential strain were labeled as Aspergillus tamari KGSS 05. The process economization for fibrinolytic production with carbon sources supplemented to the production medium were carried out with concentration of $0.25 \%, 0.5 \%, 0.75 \%, 1.0 \%$ and $1.25 \%$. The results revealed that all the carbon sources employed under the present study have enhanced the production of fibrinolytic enzyme upto $1.0 \%$ of monosaccharide and disaccharides (glucose, sucrose and maltose) at $72 \mathrm{hrs}$ of fermentation represented in Fig1-3, thereafter no significant production of fibrinolytic enzyme was observed on all the days of fermentation period. In case of monosaccharides (glucose) the maximum fibrinolytic enzyme production of $246 \mathrm{IU}$ was observed at $1.0 \%$ and where as disaccharides like maltose and sucrose yielded maximum fibrinolytic enzyme of $123 \mathrm{IU}$ and $176 \mathrm{IU}$.

Fig.1 Effect of Glucose on Fibrinolytic Enzyme Production

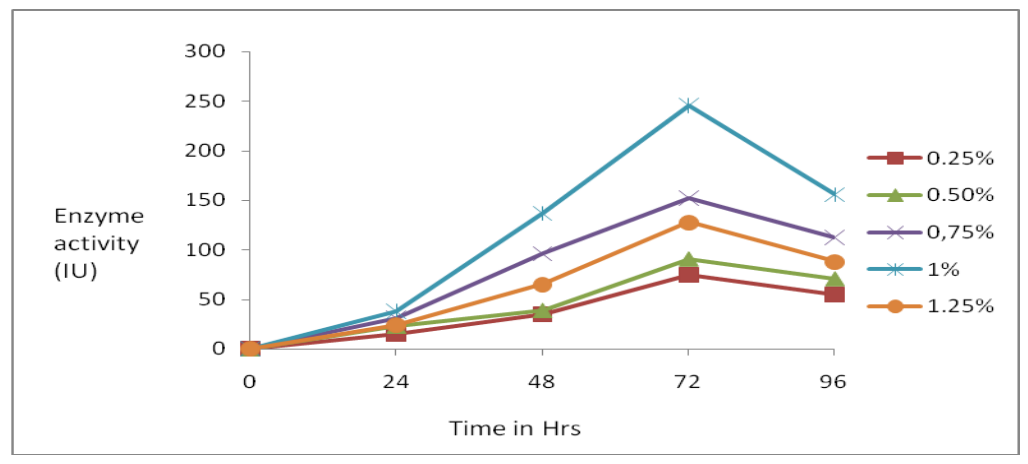

Fig.2 Effect of Sucrose on Fibrinolytic Enzyme Production

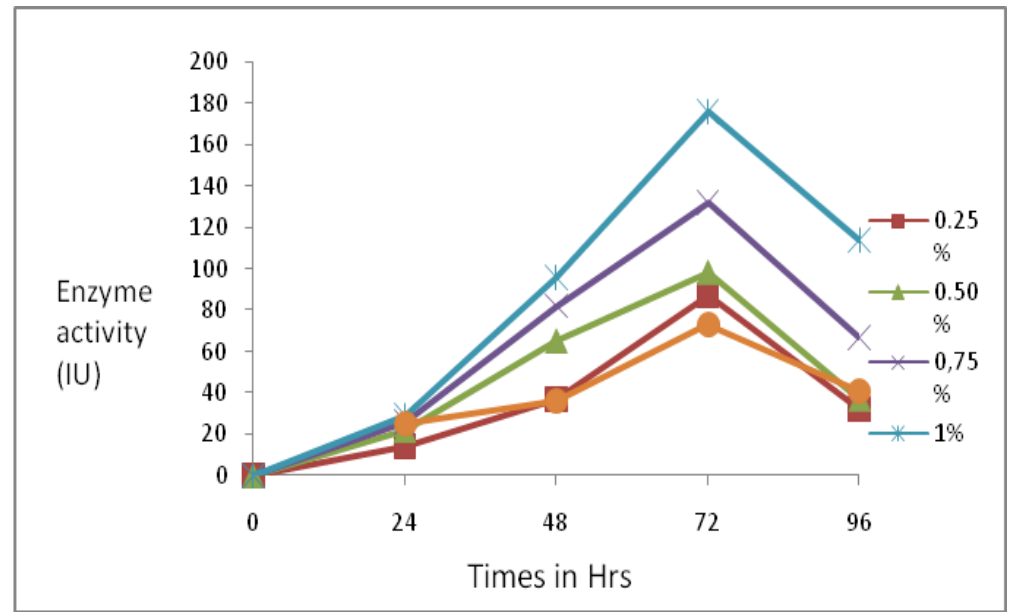


Fig.3 Effect of Maltose for Fibrinolytic Enzyme Production

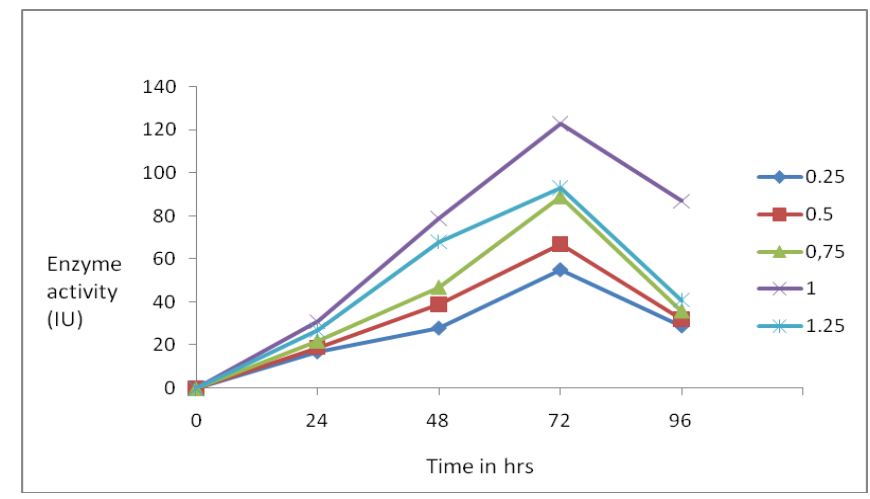

Wang et al., (2009) who showed that, based on nattokinase production, maltose was the optimal carbon source. Rashmi and Liny (2013) were reported that the carbon source, maltose showed the $2.4 \mathrm{mg} / \mathrm{ml}$ of fibrinolytic enzymes in Aspergillus niger and $2.2 \mathrm{mg} / \mathrm{ml}$ in Aspergillus flavus. Glucose showed high production rate in $2.2 \mathrm{mg} / \mathrm{ml}$ in Penicillium notatum which was relatively higher comparable to $64 \mathrm{mg} / \mathrm{l}$ in Bacillus sphaericus. Our results were coincides with the results of Essam et al.,, (2012). Essam et al.,, (2012) were reported that six types of carbon sources were investigated: maltose, manitol, fructose, glucose, sucrose, lactose at glucose is a generally preferred carbon source for growth of bacteria and it was used as reference. The results showed that, based on fibrinolytic production, mannitol was the optimal carbon source (46 unit $/ \mathrm{mL}$ ). Glucose, maltose and sucrose had similar positive effects, while lactose and sucrose performed poorly. So maltose was chosen as carbon source for the following investigations by using Bacillus lichniformis. Our results were coincides with the results of Essam et al.,, (2012).

\section{References}

Astrup T, Mullertz S. 1952. The fibrin plate method for estimating fibrinolytic activity. Arch Biochem; 40: 34651

Balaraman, K and Prabakaran. G. (2007). Production \& purification of a fibrinolytic enzyme (thrombinase) from Bacillus sphaericus. Indian Journal of Medical Research. 126: 459-464.

Essam F. Al-Juamily and Bushra H. AlZaidy. (2012). Optimization Conditions of Production Fibrinolytic Enzyme from Bacillus lichniformis B4 Local Isolate. British Journal of Pharmacology and Toxicology 3(6): 289-295

Holden RW 1990 Plasminogen activators: Pharmacology and therapy. Radiology 174 993-1001

Mukesh Kumar D J Rakshitha R. Annu M Vidhya P.. Sharon Jennifer, Sandip Prasad, M. Ravi Kumar and P.T. Kalaichelvan.P. Pakistan Journal of Biological sciences, 2013, 17 (4):529-234.

Rashmi and Liny (2013). Production and Characterization of novel Fibrinolytic Enzyme from different soil fungal sp. Int J Pharm Bio Sci 2013 July; 4(3): (B) $454-463$.

Sumi H, Nakajima N and Yatagai C 1995 A unique strong fibrinolytic enzyme (datsuwokinase) in skipjack "Shiokara", a Japanese traditional 
fermented food. Comp. Biochem. Physiol. 112B 543-547.

Takeno, T., T. Okamura, M. Sera, M. Takana, S. Fukuda and M. Ohsugi, 1999. Screening of fibrinolytic enzymes of microorganisms. The Bulletin of Mukogawa's University Natural of Science, 47: 67-72.
Wang, S., H. Chen, T. Liang and Y. Lin, 2009. A novel nattokinase produced by Pseudomonas sp., TKU015 using shrimp shells as substrate. Process Biochem., 44: 7076.

\section{How to cite this article:}

Saroj Yadav and Siddalingeshwara, K. G. 2016. Biosynthesis of Clot Busting Fibrinolytic Enzyme from Aspergillus japonicum by Supplementing Carbon Sources. Int.J.Curr.Microbiol.App.Sci. 5(3): 860-864. doi: http://dx.doi.org/10.20546/ijcmas.2016.503.099 